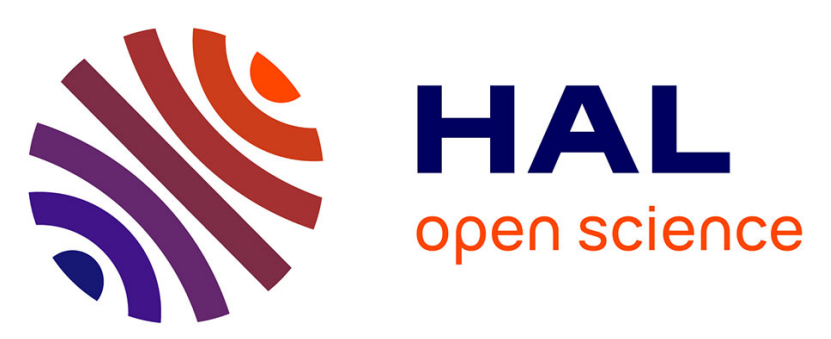

\title{
A Novel One-Dimensional Copper Mellitate Complex Featured by $\mathrm{Cu}(\mathrm{H} 2 \mathrm{O}) 2($ urea $)[\mathrm{C} 6(\mathrm{COO}) 4(\mathrm{COOH}) 2] \mathrm{n} 2 \mathrm{n}-$ Polyanions
}

\author{
Roberto Köferstein, Christian Robl
}

\section{- To cite this version:}

Roberto Köferstein, Christian Robl. A Novel One-Dimensional Copper Mellitate Complex Featured by $\mathrm{Cu}(\mathrm{H} 2 \mathrm{O}) 2$ (urea) $[\mathrm{C} 6(\mathrm{COO}) 4(\mathrm{COOH}) 2] n 2 \mathrm{n}$ - Polyanions. Journal of Inorganic and General Chemistry / Zeitschrift für anorganische und allgemeine Chemie, 2015, 641 (11), pp.1886-1891. 10.1002/zaac.201500231 . hal-02867543

HAL Id: hal-02867543 https://hal.science/hal-02867543

Submitted on 14 Jun 2020

HAL is a multi-disciplinary open access archive for the deposit and dissemination of scientific research documents, whether they are published or not. The documents may come from teaching and research institutions in France or abroad, or from public or private research centers.
L'archive ouverte pluridisciplinaire HAL, est destinée au dépôt et à la diffusion de documents scientifiques de niveau recherche, publiés ou non, émanant des établissements d'enseignement et de recherche français ou étrangers, des laboratoires publics ou privés. 


\title{
Z. Anorg. Allg. Chem. 641 (2015) 1886-1891. \\ (DOI: 10.1002/zaac.201500231)
}

\author{
https://doi.org/10.1002/zaac.201500231
}

\section{A Novel One-Dimensional Copper Mellitate Complex Featured by $\left\{\mathrm{Cu}\left(\mathrm{H}_{2} \mathrm{O}\right)_{2}(\text { urea })\left[\mathrm{C}_{6}(\mathrm{COO})_{4}(\mathrm{COOH})_{2}\right]\right\}_{\mathrm{n}}^{2 \mathrm{n}-}$ Polyanions}

\author{
Roberto Köferstein ${ }^{[a, b]}$ and Christian Robl ${ }^{*[a]}$
}

\author{
*Corresponding Author \\ [a] Institute of Inorganic and Analytical Chemistry, Friedrich-Schiller-University Jena, \\ Humboldtstrasse 8, 07743 Jena, Germany \\ [b] Institute of Chemistry, Inorganic Chemistry, Martin Luther University Halle-Wittenberg, \\ Kurt-Mothes-Strasse 2, 06120 Halle, Germany
}

\begin{abstract}
Blue monoclinic single crystals of the novel onedimensional $\quad\left[\mathrm{H}_{3} \mathrm{~N}-\left(\mathrm{CH}_{2}\right)_{6}-\mathrm{NH}_{3}\right]\left[\mathrm{Cu}\left(\mathrm{H}_{2} \mathrm{O}\right)_{2}(\right.$ urea $)\left(\mu_{2}-\mathrm{C}_{6}(\mathrm{COO})_{4}\right.$ $\left.\left.(\mathrm{COOH})_{2}\right)\right] \cdot \mathrm{H}_{2} \mathrm{O}$ coordination polymer have been prepared in aqueous solution at room temperature in the presence of 1,6diaminohexane and urea. Space group $P 2{ }_{1} / n$ (no. 14) with $a=$ 958.48(9), $b=1465.74(11), c=1821.14(12) \mathrm{pm}, \beta=97.655(8)^{\circ}$. The $\mathrm{Cu}^{2+}$ cation is coordinated in a square pyramidal manner by two oxygen atoms stemming from the dihydrogen mellitate tetraanion, one oxygen atom from the urea molecule, and two water molecules. The $\mathrm{Cu}-\mathrm{O}$ distances are between 193.3(2) and 229.4(2) $\mathrm{pm}$. The connection between $\mathrm{Cu}^{2+}$ and $\left[\mathrm{C}_{6}(\mathrm{COO})_{4}(\mathrm{COOH})_{2}\right]^{4-}$
\end{abstract}

\section{Introduction}

The connection between metal cations and multi-dentate complexing agents, like the anions of benzenecarboxylic acids leads to coordination polymers with various structural features and interesting properties [1-8]. The carboxylate groups of benzenecarboxylic acids anions are able to coordinate metal ions in flexible modes. For example, the connection between the anions of benzenehexacarboxylic acid (mellitic acid) and metal cations results in coordination polymers with chain- and layer-like structures as well as in three-dimensional frameworks (so-called MOF's) [9-22]. Besides of the fully deprotonated form, complexes with mono-, di-, tri-, and tetra-protonated anions of benzenehexacarboxylic acid are known [23-31]. The structures of such coordination polymers can be varied using rational design synthesis e.g. additional $\mathrm{N}$ - or O-donor ligands and organic amines as template molecules, respectively [28,32-42]. The obtained crystal structures also depend on the reaction conditions. Previous works show that e.g. the reaction between $\mathrm{Cu}^{2+}$ and benzenehexacarboxylic acid results either in a two-dimensional layer-like structure $[20,26,27]$ or in a three-dimensional framework [21,43]. Moreover, transition metal benzene carboxylato complexes show interesting magnetic properties [12,22,26,44-48] and they are suitable as catalysts for e.g. oxidation, reduction, and isomerisation reactions [49-53]. yields infinite chain-like polyanions parallel to [101] with a composition of $\left\{\mathrm{Cu}\left(\mathrm{H}_{2} \mathrm{O}\right)_{2} \text { (urea) }\left[\mathrm{C}_{6}(\mathrm{COO})_{4}(\mathrm{COOH})_{2}\right]\right\}_{\mathrm{n}}{ }^{2 \mathrm{n}-}$. The dihydrogen mellitate tetraanion adopts a $\mu_{2}$ coordination mode. The $\left[\left(\mathrm{H}_{3} \mathrm{~N}-\left(\mathrm{CH}_{2}\right)_{6}-\mathrm{NH}_{3}\right)\right]^{2+}$ cations are accommodated between the chains as counter cations. The hexane-1,6-diammonium cations adopt a partial synclinal conformation. The chains are connected by strong and weak hydrogen bonds. Magnetic measurements reveal a paramagnetic Curie-Weiss behaviour and a magnetic moment of $1.93 \mu_{\mathrm{B}}$ per $\mathrm{Cu}^{2+}$. Thermoanalytical investigations in air show that the complex is stable up to $135^{\circ} \mathrm{C}$. Following decomposition processes yielding $\mathrm{CuO}$.

Herein, we report on a novel one-dimensional copper dihydrogen mellitate complex with urea as additional $\mathrm{O}$ donor ligand and 1,6-diaminohexane as template molecule.

\section{Results and Discussion}

The $\mathrm{Cu}^{2+}$ cations in $\left[\mathrm{H}_{3} \mathrm{~N}-\left(\mathrm{CH}_{2}\right)_{6}-\mathrm{NH}_{3}\right]\left[\mathrm{Cu}\left(\mathrm{H}_{2} \mathrm{O}\right)_{2}\right.$ (urea) $\left.\left(\mu_{2}-\mathrm{C}_{6}(\mathrm{COO})_{4}(\mathrm{COOH})_{2}\right)\right] \cdot \mathrm{H}_{2} \mathrm{O}$ are five-coordinated in a distorted square pyramidal fashion (Fig. 1). The equatorial positions are formed by two carboxylate oxygen atoms $(\mathrm{O}(1), \quad \mathrm{O}(8))$ stemming from two different, but crystallographically equivalent, dihydrogen mellitate tetraanions, one carbonyl oxygen atom from the urea molecule (O13)) and one water molecule $(\mathrm{O}(\mathrm{w} 2))$ with $\mathrm{Cu}-\mathrm{O}$ distances between 193.3(2) and 200.2(2) pm, The apical position is occupied by the water molecule $\mathrm{O}(\mathrm{w} 3)$ with a larger bond length of 229.4(2) pm (Tab. 1). The best least-square-plane through $\mathrm{Cu}, \mathrm{O}(8), \mathrm{O}(13), \mathrm{O}(1)$ and $\mathrm{O}(\mathrm{w} 2)$ shows an average deviation of $14.5 \mathrm{pm}$. The angles between the equatorial atoms are close to the expected values of $90^{\circ}$ and $180^{\circ}$. Coordination number five could also be described by a distorted trigonal bipyramid. In that case, the equatorial plane is formed by $\mathrm{O}(\mathrm{w} 3), \mathrm{O}(\mathrm{w} 2)$, and $\mathrm{O}(13)$ and the average deviation from a best plane is only $2.5 \mathrm{pm}$. However, the angles between the atoms in the equatorial plane deviate considerably from $60^{\circ}$ and $120^{\circ}$ and the 
distances between the ligand atoms differ over a wide range. In contrast to Diniz et al. [54] a smaller deviation from the least-square-plane fitted to the equatorial atoms is not a sufficient criterion for the type of the polyhedron. More important is the comparison of angles and distances between the ligand atoms. Hence, the coordination polyhedron around $\mathrm{Cu}^{2+}$ is best described by a distorted square pyramid. Employing the method of Trömel [55] the bond order of 2.01 is very close to the expected value.

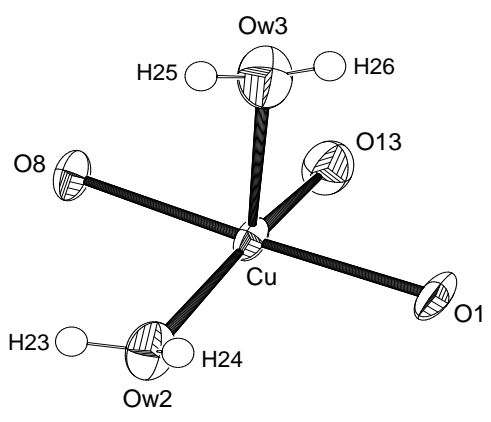

Figure 1. The coordination environment of $\mathrm{Cu}^{2+}$ (Ellipsoids are given at $50 \%$ probability, arbitrary radii for hydrogen atoms).

Table 1. The Coordination Environment of $\mathrm{Cu}^{2+}$

\begin{tabular}{llll}
\hline \multicolumn{4}{l}{ bond lengths (pm) } \\
\hline $\mathrm{Cu}-\mathrm{O}(8)$ & $193.3(2)$ & $\mathrm{Cu}-\mathrm{O}(\mathrm{w} 2)$ & $200.2(2)$ \\
$\mathrm{Cu}-\mathrm{O}(13)$ & $196.5(2)$ & $\mathrm{Cu}-\mathrm{O}(\mathrm{w} 3)$ & $229.4(2)$ \\
$\mathrm{Cu}-\mathrm{O}(1)$ & $194.9(2)$ & & \\
\hline bond angles $\left({ }^{\circ}\right)$ & & & \\
\hline $\mathrm{O}(8)-\mathrm{Cu}-\mathrm{O}(1)$ & $177.32(8)$ & $\mathrm{O}(1)-\mathrm{Cu}-\mathrm{O}(13)$ & $90.58(8)$ \\
$\mathrm{O}(8)-\mathrm{Cu}-\mathrm{O}(13)$ & $87.28(8)$ & $\mathrm{O}(1)-\mathrm{Cu}-\mathrm{O}(\mathrm{w} 2)$ & $94.47(8)$ \\
$\mathrm{O}(8)-\mathrm{Cu}-\mathrm{O}(\mathrm{w} 2)$ & $88.04(8)$ & $\mathrm{O}(1)-\mathrm{Cu}-\mathrm{O}(\mathrm{w} 3)$ & $89.32(8)$ \\
$\mathrm{O}(8)-\mathrm{Cu}-\mathrm{O}(\mathrm{w} 3)$ & $89.69(8)$ & $\mathrm{O}(13)-\mathrm{Cu}-\mathrm{O}(\mathrm{w} 3)$ & $105.16(8)$ \\
$\mathrm{O}(\mathrm{w} 2)-\mathrm{Cu}-\mathrm{O}(\mathrm{w} 3)$ & $91.59(9)$ & $\mathrm{O}(13)-\mathrm{Cu}-\mathrm{O}(\mathrm{w} 2)$ & $162.57(9)$
\end{tabular}

The dihydrogen mellitate tetraanion (dihydrogen benzenehexacarboxylate tetraanion) (Fig. 2) is approximately planar with respect to the carbon skeleton. The largest deviation from a plane fitted to the carbon atoms is $17.4 \mathrm{pm}(\mathrm{C}(9))$. The carboxylate groups are twisted against the $\mathrm{C}_{6}$-ring by $46.7^{\circ}(\mathrm{C}(7), \mathrm{O}(1), \mathrm{O}(2)), 60.1^{\circ}(\mathrm{C}(8)$, $\mathrm{O}(3), \mathrm{O}(4)), 50.2^{\circ}(\mathrm{C}(9), \mathrm{O}(5), \mathrm{O}(6)), 113.8^{\circ}(\mathrm{C}(10), \mathrm{O}(7)$, $\mathrm{O}(8)), 44.5$ (C11), $\mathrm{O}(9), \mathrm{O}(10))$, and $64.8^{\circ}(\mathrm{C}(12), \mathrm{O}(11)$, $\mathrm{O}(12)$ ), respectively. The $\mathrm{C}-\mathrm{O}$ bond lengths of the deprotonated carboxylate groups range from 123.1(3) to 127.1(3) pm. On the other hand the $\mathrm{C}-\mathrm{O}$ bonds of the $\mathrm{COOH}$ groups, which are in the meta position, are between 121.7(3) and 129.8(3) pm (Tab. 2). $\mathrm{COOH}$ groups in meta position are also found in calcium dihydrogen mellitate [29], whereas in e. g. copper-, cobalt- and nickel dihydrogen mellitates with $\mathrm{N}$-donor ligands the carboxylic groups are in para position $[28,30,34,45]$. The urea molecule is planar and can be described by the point group $\mathrm{C}_{\mathrm{s}}$ in good approximation. The $\mathrm{C}-\mathrm{O}$ bond length is $126.1(3) \mathrm{pm}$ and the $\mathrm{C}-\mathrm{N}$ distances are 132.2(4) and 134.3(4) pm (Tab. 2). In spite of the coordination to $\mathrm{Cu}^{2+}$ the $\mathrm{C}-\mathrm{O}$ bond length does not significantly differ from the one found in the uncoordinated urea molecule [56,57].

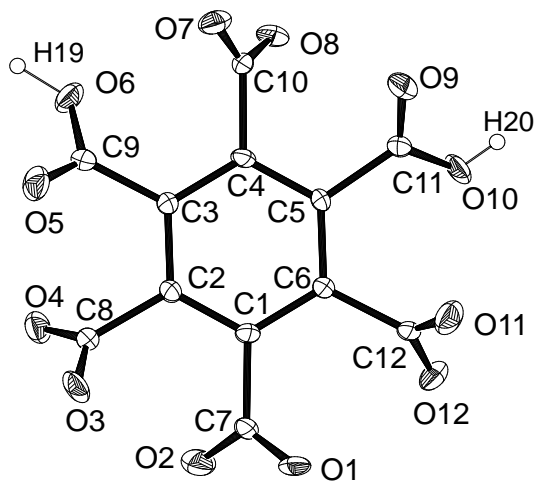

Figure 2. The dihydrogen mellitate tetraanion (Ellipsoids are given at $50 \%$ probability, arbitrary radii for hydrogen atoms).

Table 2. Bond Lengths (pm) of the Dihydrogen Mellitate Tetraanion, the Urea Molecule and the Hexane-1,6-diammonium Cation

\begin{tabular}{|c|c|c|c|c|c|}
\hline \multicolumn{6}{|c|}{ Dihydrogen Mellitate Tetraanion } \\
\hline $\mathrm{C}(1)-\mathrm{C}(2)$ & 139.3(3) & $\mathrm{C}(4)-\mathrm{C}(10)$ & $151.0(3)$ & $\mathrm{C}(10)-\mathrm{O}(7)$ & $124.6(3)$ \\
\hline $\mathrm{C}(1)-\mathrm{C}(6)$ & $140.7(3)$ & $\mathrm{C}(5)-\mathrm{C}(11)$ & $151.4(3)$ & $\mathrm{C}(10)-\mathrm{O}(8)$ & $125.8(3)$ \\
\hline $\mathrm{C}(2)-\mathrm{C}(3)$ & $140.0(3)$ & $\mathrm{C}(6)-\mathrm{C}(12)$ & 152.1(3) & $\mathrm{C}(11)-\mathrm{O}(9)$ & $121.8(3)$ \\
\hline $\mathrm{C}(3)-\mathrm{C}(4)$ & 139.9(3) & $\mathrm{C}(7)-\mathrm{O}(1)$ & 127.1(3) & $\mathrm{C}(11)-\mathrm{O}(10)$ & $129.0(3)$ \\
\hline $\mathrm{C}(4)-\mathrm{C}(5)$ & 139.4(3) & $\mathrm{C}(7)-\mathrm{O}(2)$ & 123.1(3) & $\mathrm{C}(12)-\mathrm{O}(11)$ & $124.5(3)$ \\
\hline $\mathrm{C}(5)-\mathrm{C}(6)$ & $139.6(3)$ & $\mathrm{C}(8)-\mathrm{O}(3)$ & $126.8(3)$ & $\mathrm{C}(12)-\mathrm{O}(12)$ & $125.9(3)$ \\
\hline $\mathrm{C}(1)-\mathrm{C}(7)$ & $151.9(3)$ & $\mathrm{C}(8)-\mathrm{O}(4)$ & 124.1(3) & $\mathrm{O}(6)-\mathrm{H}(19)$ & $102(4)$ \\
\hline $\mathrm{C}(2)-\mathrm{C}(8)$ & $151.7(3)$ & $\mathrm{C}(9)-\mathrm{O}(5)$ & $121.7(3)$ & $\mathrm{O}(10)-\mathrm{H}(20)$ & $76(4)$ \\
\hline $\mathrm{C}(3)-\mathrm{C}(9)$ & $150.9(3)$ & $\mathrm{C}(9)-\mathrm{O}(6)$ & $129.8(3)$ & & \\
\hline \multicolumn{6}{|l|}{ Urea } \\
\hline $\mathrm{O}(13)-\mathrm{C}(13)$ & 126.1(3) & $\mathrm{N}(3)-\mathrm{H}(27)$ & $91(4)$ & $\mathrm{N}(4)-\mathrm{H}(30)$ & $82(4)$ \\
\hline $\mathrm{C}(13)-\mathrm{N}(4)$ & $132.2(4)$ & $\mathrm{N}(3)-\mathrm{H}(28)$ & $80(4)$ & $\mathrm{N}(4)-\mathrm{H}(29)$ & $86(4)$ \\
\hline $\mathrm{C}(13)-\mathrm{N}(3)$ & 134.3(4) & & & & \\
\hline \multicolumn{6}{|c|}{ Hexane-1,6-diammonium Cation } \\
\hline $\mathrm{N}(1)-\mathrm{C}(14)$ & 149.1(4) & $\mathrm{C}(17)-\mathrm{C}(18)$ & $152.2(4)$ & $\mathrm{N}(1)-\mathrm{H}(15)$ & $95(5)$ \\
\hline $\mathrm{N}(2)-\mathrm{C}(19)$ & $147.4(4)$ & $\mathrm{C}(18)-\mathrm{C}(19)$ & $150.2(5)$ & $\mathrm{N}(2)-\mathrm{H}(16)$ & $82(5)$ \\
\hline$C(14)-C(15)$ & $150.6(4)$ & $\mathrm{N}(1)-\mathrm{H}(14)$ & 83(4) & $\mathrm{N}(2)-\mathrm{H}(17)$ & $80(5)$ \\
\hline $\mathrm{C}(15)-\mathrm{C}(16)$ & 152.1(4) & $\mathrm{N}(1)-\mathrm{H}(13)$ & $95(3)$ & $\mathrm{N}(2)-\mathrm{H}(18)$ & $92(5)$ \\
\hline $\mathrm{C}(16)-\mathrm{C}(17)$ & $150.9(4)$ & & & & \\
\hline
\end{tabular}

The $\mathrm{Cu}^{2+}$ cations are linked by the $\left[\mathrm{C}_{6}(\mathrm{COO})_{4}(\mathrm{COOH})_{2}\right]^{4-}$ anions to form infinite chain-like polyanions with a composition of $\quad\left\{\mathrm{Cu}\left(\mathrm{H}_{2} \mathrm{O}\right)_{2}(\right.$ urea $)\left[\mu_{2^{-}}\right.$ $\left.\left.\mathrm{C}_{6}(\mathrm{COO})_{4}(\mathrm{COOH})_{2}\right]\right\}_{\mathrm{n}}{ }^{2 \mathrm{n}-}$ (Fig. 3). The dihydrogen mellitate tetraanion connects two copper-ions and adopts a $\mu_{2}$ coordination mode. The two carboxylate groups $(\mathrm{C}(10)$, $\mathrm{C}(7)$ ) bound to $\mathrm{Cu}^{2+}$ are in the para position and act as monodentate ligands. Surprisingly, the deprotonated carboxylate groups with $\mathrm{C}(8)$ and $\mathrm{C}(12)$ are not connected to $\mathrm{Cu}^{2+}$. The polyanionic chains extend along [101] and they are stacked in ...ABAB... sequence in the [010] direction. A $\pi-\pi$ interaction between the aromatic $\mathrm{C}_{6}$-rings can be excluded, because of the large distance between each other, which corresponds to the crystallographic b-axis $[58,59]$ (Fig. 4). The linear charge density of the polyanionic chains is $1.85 \cdot 10^{-3} \mathrm{e} / \mathrm{pm}(541 \mathrm{pm} /$ unit charge $)$. The negative charge is balanced by hexane-1,6-diammonium cations intercalated between neighbouring chains. The skeleton of the hexane1,6-diammonium cation does not take a full all-trans (antiperiplanar) conformation (Fig. 5a). The ammonium group $\mathrm{N}(2)$ is rotated away which leads to a synclinal conformation as seen in the Newman projection along the 
$\mathrm{C}(18)-\mathrm{C}(19)$ bond in Fig. 5b. The $\mathrm{C}-\mathrm{N}$ bond lengths are 149.1(4) and 147.4(4) pm and the $\mathrm{C}-\mathrm{C}$ bonds range from $150.2(5)$ to 152.2 (4) pm (Tab. 2). In the crystal structure of e.g. hexane-1,6-diammonium bis(dihydrogenarsenate) [60] it was also found that the hexane-1,6-diammonium cation does not take the conformation with the lowest energy.

Coordination polymers with chain-like polyanions and intercalated organic cations are also obtained e.g. by the reaction between transition metal cations and benze-1,2,4,5tetracarboxylic acid in the presence of amines [37,61].

\section{$\langle$ Figure 3 >}

(Due to its large size Fig. 3 is placed at the end of the document)

\section{$<$ Figure 4 >}

\section{(Due to its large size Fig. 4 is placed at the end of the document)}

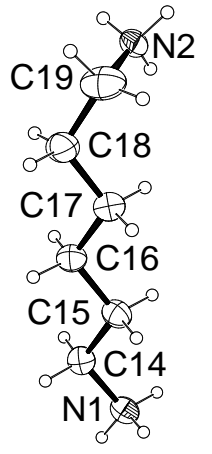

(a)

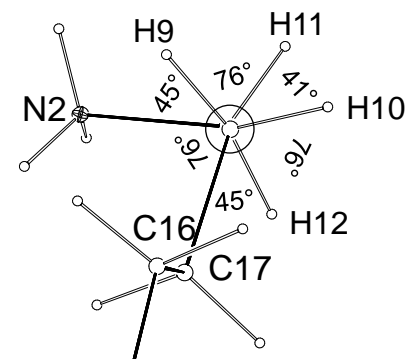

(b)

\begin{tabular}{lcc}
$\mathrm{N}(2)-\mathrm{H}(17) \cdots \mathrm{O}(12)$ & 312.4 & 155 \\
$\mathrm{~N}(2)-\mathrm{H}(18) \cdots \mathrm{O}(7)$ & 275.2 & 166 \\
$\mathrm{~N}(3)-\mathrm{H}(27) \cdots \mathrm{O}(11)$ & 305.8 & 150 \\
$\mathrm{~N}(3)-\mathrm{H}(28) \cdots \mathrm{O}(1)^{*}$ & 327.9 & 155 \\
$\mathrm{~N}(4)-\mathrm{H}(29) \cdots \mathrm{O}(\mathrm{w} 3)$ & 293.4 & 162 \\
$\mathrm{~N}(4)-\mathrm{H}(30) \cdots \mathrm{O}(3)^{*}$ & 297.7 & 166 \\
\hline & $\mathrm{O} \cdots \mathrm{O}$ Distance & $\mathrm{O}-\mathrm{H} \cdots \mathrm{O}$ Angle \\
& $(\mathrm{pm})$ & $\left({ }^{\circ}\right)$ \\
\hline $\mathrm{O}(6)-\mathrm{H}(19) \cdots \mathrm{O}(12)^{*}$ & 253.4 & 172 \\
$\mathrm{O}(10)-\mathrm{H}(20) \cdots \mathrm{O}(3)^{*}$ & 246.5 & 173 \\
$\mathrm{O}(\mathrm{w} 1)-\mathrm{H}(21) \cdots \mathrm{O}(11)$ & 281.3 & 155 \\
$\mathrm{O}(\mathrm{w} 1)-\mathrm{H}(22) \cdots \mathrm{O}(11)$ & 275.4 & 175 \\
$\mathrm{O}(\mathrm{w} 2)-\mathrm{H}(23) \cdots \mathrm{O}(9)$ & 293.3 & 173 \\
$\mathrm{O}(\mathrm{w} 2)-\mathrm{H}(24) \cdots \mathrm{O}(5)$ & 270.1 & 161 \\
$\mathrm{O}(\mathrm{w} 3)-\mathrm{H}(25) \cdots \mathrm{O}(4)$ & 292.8 & 164 \\
$\mathrm{O}(\mathrm{w} 3)-\mathrm{H}(26) \cdots \mathrm{O}(\mathrm{w} 1)$ & 280.8 & 167 \\
\end{tabular}

* Hydrogen bonds between neighbouring chains

The polyanion chains are linked by hydrogen bonds. The hydroxo groups $\mathrm{O}(6)-\mathrm{H}(19)$ and $\mathrm{O}(10)-\mathrm{H}(20)$ of the dihydrogen mellitate tetraanion form very strong hydrogen bonds to the carboxylate oxygen atoms $\mathrm{O}(12)$ and $\mathrm{O}(3)$ of neighbouring chains. The amino groups $(\mathrm{N}(3), \mathrm{N}(4))$ of the urea molecule act as proton donators in interchain hydrogen bonds to carboxylate oxygen atoms of medium and low strength. The coordinated water molecules $\mathrm{O}(\mathrm{w} 2)$ and $\mathrm{O}(\mathrm{w} 3)$ are involved in hydrogen bonds within the polyanion chain as proton donators. Additionally, $\mathrm{O}(\mathrm{w} 3)$ acts as proton acceptor to the amino group $\mathrm{N}(4)-\mathrm{H}(29)$. The uncoordinated water molecule $\mathrm{O}(\mathrm{w} 1)$ and the hexane-1,6-diammonium cation stabilize the structure by strong to weak hydrogen bonds (Tab. 3). The hydrogen bonds connect the polyanion chains to a supramolecular three-dimensional network. As seen in Table 3 the deprotonated carboxylate groups $\mathrm{C}(8)$ and $\mathrm{C}(12)$, not bond to $\mathrm{Cu}^{2+}$, act as proton acceptors in several strong and very strong hydrogen bonds. Both the carbonyl oxygen atom $\mathrm{O}(13)$ and the carboxylate oxygen atom $\mathrm{O}(8)$ are not involved in any hydrogen bonds.

Fig. 6 shows both the XRD pattern of powdered $\left[\mathrm{H}_{3} \mathrm{~N}\right.$ $\left.\left(\mathrm{CH}_{2}\right)_{6}-\mathrm{NH}_{3}\right]\left[\mathrm{Cu}\left(\mathrm{H}_{2} \mathrm{O}\right)_{2}(\right.$ urea $\left.)\left(\mu_{2}-\mathrm{C}_{6}(\mathrm{COO})_{4}(\mathrm{COOH})_{2}\right)\right] \cdot \mathrm{H}_{2} \mathrm{O}$ crystals and the calculated pattern obtained from the single crystal data. As seen, the measured pattern is consistent with the calculated pattern, suggesting that the synthesis leads to a single phase product.

Figure 5. (a) The hexane-1,6-diammionium cation (50\% probability ellipsoids, arbitrary radii for hydrogen atoms). (b) Newman projection along the $\mathrm{C}(18)-\mathrm{C}(19)$ bond.

Table 3. Hydrogen bonds

\begin{tabular}{lcc}
\hline & $\begin{array}{c}\mathrm{N} \cdots \mathrm{O} \text { Distance } \\
(\mathrm{pm})\end{array}$ & $\begin{array}{c}\mathrm{N}-\mathrm{H} \cdots \mathrm{O} \text { Angle } \\
\left({ }^{\circ}\right)\end{array}$ \\
\hline $\mathrm{N}(1)-\mathrm{H}(13) \cdots \mathrm{O}(\mathrm{w} 1)$ & 280.6 & 166 \\
$\mathrm{~N}(1)-\mathrm{H}(14) \cdots \mathrm{O}(7)$ & 290.2 & 169 \\
$\mathrm{~N}(1)-\mathrm{H}(15) \cdots \mathrm{O}(4)$ & 286.9 & 164 \\
$\mathrm{~N}(2)-\mathrm{H}(16) \cdots \mathrm{O}(2)$ & 291.2 & 142
\end{tabular}




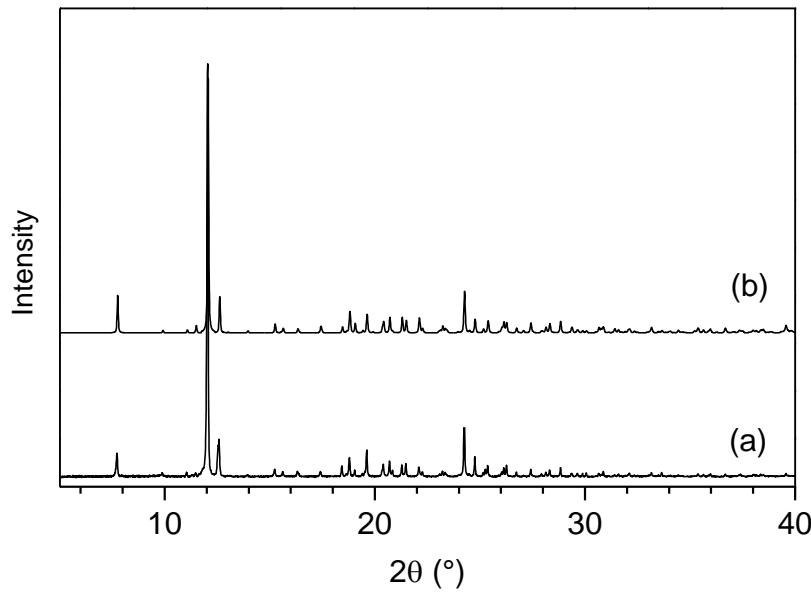

Figure 6. X-ray powder diffraction patterns of $\left[\mathrm{H}_{3} \mathrm{~N}-\left(\mathrm{CH}_{2}\right)_{6^{-}}\right.$ $\left.\mathrm{NH}_{3}\right]\left[\mathrm{Cu}\left(\mathrm{H}_{2} \mathrm{O}\right)_{2}(\right.$ urea $\left.)\left(\mu_{2}-\mathrm{C}_{6}(\mathrm{COO})_{4}(\mathrm{COOH})_{2}\right)\right] \cdot \mathrm{H}_{2} \mathrm{O}$. (a) measured pattern, (b) calculated pattern.

TGA/DTA studies (Fig. 7) were carried out in air from room temperature to $1000{ }^{\circ} \mathrm{C}$ at a heating rate of $10 \mathrm{~K} \mathrm{~min}^{-1}$. The compound is stable up to $135{ }^{\circ} \mathrm{C}$. The following decomposition starts with an endothermic process due to the loss of water. Strong exothermic processes between approximately 240 and $660{ }^{\circ} \mathrm{C}$ lead to a total weight loss of $88.1 \%$. Between 660 and $1000{ }^{\circ} \mathrm{C}$ a slight weight increase of $0.7 \%$ is observed leading to a final weight loss of $87.6 \%$ (calc. $87.4 \%$ ). The residue was $\mathrm{CuO}$ which was identified by X-ray powder diffraction. The weight increase can be explained by a partial formation of $\mathrm{Cu}^{+}$during the decomposition process and the following re-oxidation in air to $\mathrm{Cu}^{2+}$ at high temperatures. The reduction of $\mathrm{Cu}^{2+}$ has also been observed during the decomposition of other copper carboxylates [62-64].

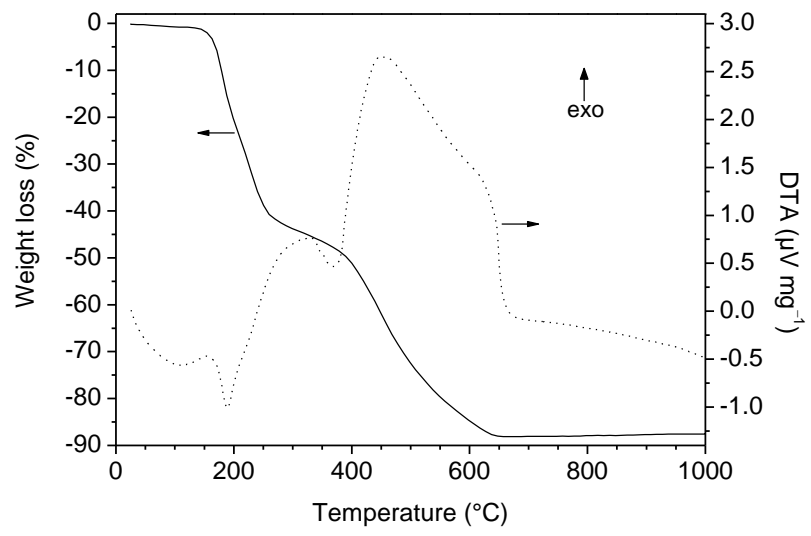

Figure 7: Thermal analysis of $\left[\mathrm{H}_{3} \mathrm{~N}-\left(\mathrm{CH}_{2}\right)_{6-}\right.$ $\left.\mathrm{NH}_{3}\right]\left[\mathrm{Cu}\left(\mathrm{H}_{2} \mathrm{O}\right)_{2}(\right.$ urea $\left.)\left(\mu_{2}-\mathrm{C}_{6}(\mathrm{COO})_{4}(\mathrm{COOH})_{2}\right)\right] \cdot \mathrm{H}_{2} \mathrm{O}$.

The IR spectrum is shown in Fig. 8. O-H and $\mathrm{N}-\mathrm{H}$ stretching vibrations are in the range of 3500 to $3200 \mathrm{~cm}^{-1}$. A sharp band at $2944 \mathrm{~cm}^{-1}$ reflects the $\mathrm{C}-\mathrm{H}$ stretching mode Bands at 1710, 1670, 1617, 1580, 1504, 1427, 1325 and $1144 \mathrm{~cm}^{-1}$ represent $\mathrm{C}-\mathrm{O}, \mathrm{C}-\mathrm{N}$ and $\mathrm{N}-\mathrm{H}$ vibrations. The compound contains three different organic molecules, therefore an assignment in detail is not possible. Absorption bands at 1710 and $1670 \mathrm{~cm}^{-1}$ are due to the $\mathrm{C}-\mathrm{O}$ stretching vibration of the urea carbonyl group and the $\mathrm{COOH}$ group of the dihydrogen mellitate tetraanion. The bands at 1580 and $1325 \mathrm{~cm}^{-1}$ are mainly caused by the asymmetrical and symmetrical stretching vibration of the deprotonated carboxylate groups. The $\mathrm{N}-\mathrm{H}$ rocking mode appears at 1144 $\mathrm{cm}^{-1}[65-68]$.

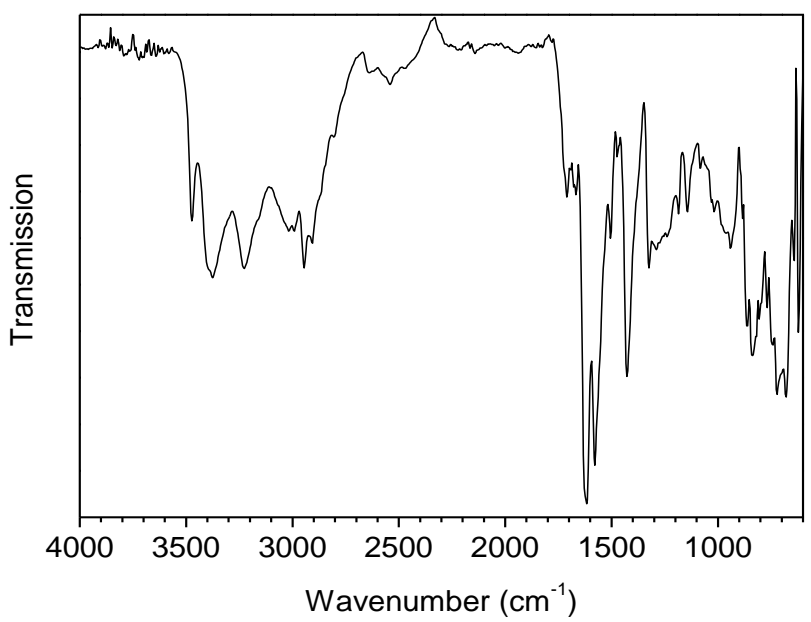

Figure 8: IR spectrum of $\left[\mathrm{H}_{3} \mathrm{~N}-\left(\mathrm{CH}_{2}\right)_{6}-\mathrm{NH}_{3}\right]\left[\mathrm{Cu}\left(\mathrm{H}_{2} \mathrm{O}\right)_{2}(\right.$ urea $)\left(\mu_{2-}\right.$ $\left.\left.\mathrm{C}_{6}(\mathrm{COO})_{4}(\mathrm{COOH})_{2}\right)\right] \cdot \mathrm{H}_{2} \mathrm{O}$

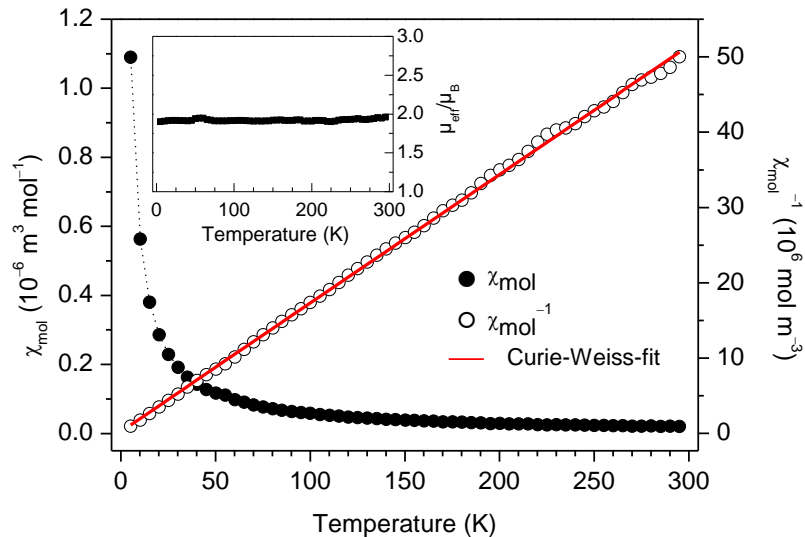

Figure 9: Susceptibility versus temperature of $\left[\mathrm{H}_{3} \mathrm{~N}-\left(\mathrm{CH}_{2}\right)_{6^{-}}\right.$ $\left.\mathrm{NH}_{3}\right]\left[\mathrm{Cu}\left(\mathrm{H}_{2} \mathrm{O}\right)_{2}\right.$ (urea) $\left.\left(\mu_{2}-\mathrm{C}_{6}(\mathrm{COO})_{4}(\mathrm{COOH})_{2}\right)\right] \cdot \mathrm{H}_{2} \mathrm{O}$. The inset shows the magnetic moment depending on temperature.

The magnetic susceptibility of $\left[\mathrm{H}_{3} \mathrm{~N}-\left(\mathrm{CH}_{2}\right)_{6}\right.$ $\left.\mathrm{NH}_{3}\right]\left[\mathrm{Cu}\left(\mathrm{H}_{2} \mathrm{O}\right)_{2}\right.$ (urea) $\left.\left(\mu_{2}-\mathrm{C}_{6}(\mathrm{COO})_{4}(\mathrm{COOH})_{2}\right)\right] \cdot \mathrm{H}_{2} \mathrm{O}$ was measured between 5 and $295 \mathrm{~K}$ (Fig. 9). The compound shows a paramagnetic behaviour. The change of the susceptibility followed the Curie-Weiss law with a Curie constant of $\mathrm{C}=5.86 \cdot 10^{-6} \mathrm{~m}^{3} \mathrm{~K} \mathrm{~mol}^{-1}$. The observed Weiss temperature of $\Theta=-1.47 \mathrm{~K}$ suggests a possible very weak antiferromagnetic interaction. From the Curie constant the magnetic moment is calculated as $\mu_{\mathrm{mag}}=1.93 \mu_{\mathrm{B}}$ per $\mathrm{Cu}^{2+}$. The slightly larger value than the theoretical spin-only one of $1.73 \mu_{\mathrm{B}}$ for $\mathrm{Cu}^{2+}$ can be explained by a weak spin-orbit 
interaction [69]. Magnetic moments larger than the spinonly value are usually found in $\mathrm{Cu}^{2+}$ complexes [70].

\section{Conclusions}

In summary, we reported on the synthesis and crystal structure of a novel one-dimensional $\mathrm{Cu}(\mathrm{II})$-dihydrogen mellitate coordination polymer in the presence of urea as additional O-donor ligand and 1,6-diaminohexane as template agent. The connection between the $\mathrm{Cu}^{2+}$-ions and the dihydrogen mellitate tetraanion leads to infinite chainlike polyanions. The hexane-1,6-diammonium cations adopt a partial synclinal conformation and act as counter ions intercalated between neighbouring chains. The coordination polymer is thermally stable up to $135{ }^{\circ} \mathrm{C}$ and magnetic measurements reveal a paramagnetic Curie-Weiss behaviour between 5 and $295 \mathrm{~K}$.

\section{Experimental Section}

Single crystals of $\left[\mathrm{H}_{3} \mathrm{~N}-\left(\mathrm{CH}_{2}\right)_{6}-\mathrm{NH}_{3}\right]\left[\mathrm{Cu}\left(\mathrm{H}_{2} \mathrm{O}\right)_{2}(\right.$ urea $)\left(\mu_{2^{-}}\right.$ $\left.\left.\mathrm{C}_{6}(\mathrm{COO})_{4}(\mathrm{COOH})_{2}\right)\right] \cdot \mathrm{H}_{2} \mathrm{O}$ were synthesized in the presence of 1,6diaminonohexane and urea. An aqueous solution of $5 \mathrm{ml} 0.1 \mathrm{M}$ $\mathrm{Cu}\left(\mathrm{NO}_{3}\right)_{2}$ was added to a solution of $5 \mathrm{ml} 0.2 \mathrm{M}$ 1,6diaminonohexane. A precipitate, which appeared intermediately, was dissolved by addition of a small amount of $2 \mathrm{M} \mathrm{HNO}_{3}$. Then a solution of $5 \mathrm{ml} 0.03 \mathrm{M}$ sodium benzenehexacarboxylate and $0.06 \mathrm{~g}$ urea were added. The resulting solution was allowed to evaporate at room temperature yielding blue, water soluble cube-like crystals. Results of elemental analysis: (molecular weight 634.01) C 35.15 (calc. 35.99); H 4.87 (4.77); N 8.81 (8.84)\%.

IR-ATR $\left(\mathrm{cm}^{-1}\right)$ : 3473(m), 3375(m), 3227(m) 2944(m), 1710(w), 1670(w), 1617(s), 1580(s), 1504(w), 1427(s), 1325(m), 1188(w), 1144(w), 1085(w), 1019(w), 940(m), 865(m), 838(m), 807(w), 768(w), 722(s), 680(s), 620(m).

ATR Fourier transformed infrared (IR-ATR) measurements were carried out at room temperature using a Bio-rad FTS 25. Thermoanalytic measurements were performed in flowing air using a Netzsch STA429 device. Temperature dependent magnetizations were measured at $\mu_{0} \mathrm{H}=0.3 \mathrm{~T}$ in the temperature range of 5 to 295 K using a Quantum Design PPMS 9. The X-ray powder diffraction pattern was recorded at room temperature on a Bruker D8-Advance diffractometer, equipped with a one-dimensional silicon strip detector $\left(\right.$ LynxEye ${ }^{\mathrm{TM}}$ ) and operating with $\mathrm{Cu}-\mathrm{K} \alpha$ radiation. X-ray single crystal structure determination was performed on a Siemens $\mathrm{P} 4$ four-circle diffractometer (MoK $\alpha$, graphite monochromator) in a theta range up to $25.00^{\circ}$. Numerical absorption corrections have been applied.

An empirical extinction parameter has been introduced (0.0018(2)). The phase problem was solved by direct methods. Full matrix least squares refinement employing $|F|^{2}$ made use of the SHELXTL program suite [71]. Some of the hydrogen atoms have been placed into calculated positions, further hydrogen atom positions could be taken from Difference Fourier maps. They were allowed to refine with different common isotropic displacement parameters. Crystallographic data are given in Table 4.

Further details concerning the crystal structure analysis have been deposited with Cambridge Crystallographic Data Centre, The Director, CCDC, 12 Union Road, Cambridge CB21EZ, UK, Fax +(1223)336-033, e-mail data_request@ccdc.cam.ac.uk, www.ccdc.cam.ac.uk/data_request.cif under CCDC 1060668.

Table 4. Crystallographic Data

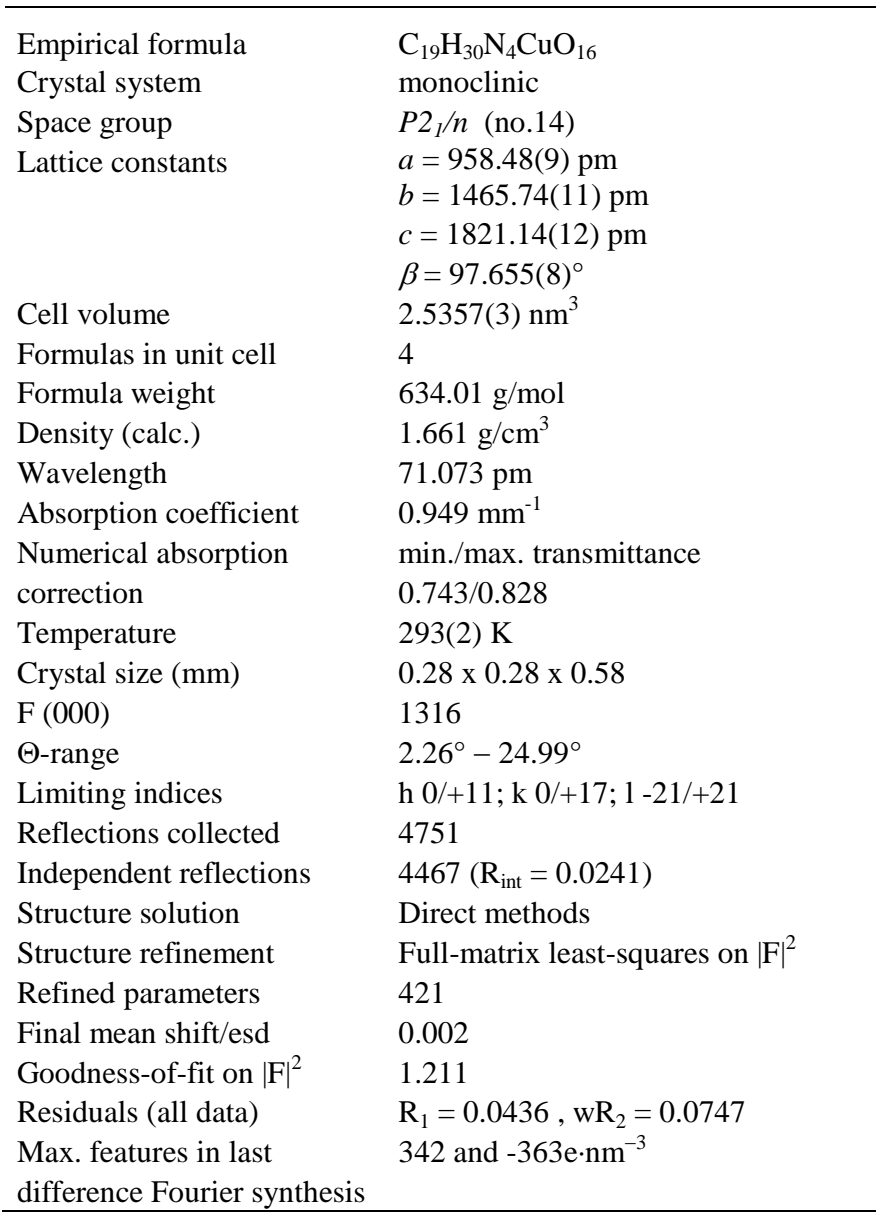

\section{Acknowledgement}

We are grateful to Mrs Christina Apfel for recording the thermoanalytical data. 


\section{References}

[1] G. Férey, Chem. Soc. Rev. 2008, 37, 191-214.

[2] L.-M. Zhao, H.-H. Li, Y. Wu, S.-Y. Zhang, Z.-J. Zhang, W. Shi, P. Cheng, D.-Z. Liao, S.-P. Yan, Eur. J. Inorg. Chem. 2010, 1983-1990.

[3] L. Karanovic, D. Poleti, G.A. Bogdanovic, A. Spasojevic-de Bire, Acta Cryst. 1999, C55, 911-913.

[4] M. Singh, D. Kumar, J. Thomas, A. Ramanan, J. Chem. Sci. 2010, 122, 757-769.

[5] B. Paul, B. Zimmermann, K.M. Fromm, C. Janiak, Z. Anorg. Allg. Chem. 2004, 630, 1650-1654.

[6] P. Lightfoot and A. Snedden, J. Chem. Soc., Dalton Trans. 1999, 3549-3551.

[7] R. Köferstein and C. Robl, Z. Anorg. Allg. Chem. 2014, 640, 310-316.

[8] O.M. Yaghi, M. O'Keeffe, N.W. Ockwig, H.K. Chae, M. Eddaoudi, J. Kim, Nature 2003, 423, 705-714.

[9] A. Kyono, M. Kimata, T. Hatta, Inorg. Chim. Acta, 2004, $357,2519-2524$.

[10] L.P. Wu, M. Munakata, T. Kuroda-Sowa, M. Maekawa, Y. Suenaga, Inorg. Chim. Acta, 1996, 249, 183-189

[11] I. Mihalcea, C. Volkringer, N. Henry, T. Loiseau, Inorg. Chem. 2012, 51, 9610-9618.

[12] M.-Y. Li and S.C. Sevov, Cryst. Eng. Comm. 2013, 15, $1225-1234$

[13] C. Robl and S. Hentschel, Z. Naturforsch. 1991, 46b, $1188-1192$.

[14] J. Olchowka, C. Falaise, C. Volkringer, N. Henry, T. Loiseau, Chem. Eur. J. 2013, 19, 2012-2022.

[15] A. Deluzet and O. Guillou, Acta Cryst. 2003, C59, $\mathrm{m} 277-\mathrm{m} 279$

[16] L.P. Wu, M. Munakata, M. Yamamoto, T. Kuroda-Sowa, M Maekawa, J. Coord. Chem. 1996, 37, 361-369.

[17] X. Tang, S. Yue, P. Li, N. Wang, Y. Liu, J. Rare Earths 2008 26, 800-803.

[18] C. Robl and S. Hentschel, Z. Naturforsch. 1992, 47b, 1561-1564.

[19] Z.-F. Li, C.-X. Wang, P. Wang, Q.-H. Zhang, Acta Cryst. 2006, E62, m914-m915

[20] M.-G. Zhao, C.-Q. Li, J.-M. Shi, W. Xu, Trans. Met. Chem. 2003, $28,525-528$

[21] E. Yang, Y.-Y. Qin, X.-Y. Cao, Q.-P. Lin, P.-X. Yin, Y.-G. Yao, Chinese J. Struct. Chem. 2008, 27, 985-989.

[22] L.P. Wu, M. Yamamoto, T. Kuroda-Sowa, M. Maekawa, J. Kukui, M. Munakata, Inorg. Chim. Acta, 1995, 239, 165-169.

[23] C. Volkringer, T. Loiseau, N. Guillou, G. Ferey, D. Popov, M. Burghammer, C. Riekel, Solid State Sci. 2013, 26, 38-44.

[24] H. Xie and G. Lu, J. Coord. Chem. 2015, published online, DOI: 10.1080/00958972.2015.1023717.

[25] C.-X. Wang, Z.-F. Li, P. Wang, Z. Kristallogr. 2008, 223 , $87-88$.

[26] H. Tamura, K. Ogawa, W. Mori, J. Cryst. Spec. Res. 1989, 19, 203-213.

[27] H. Tamura, K. Ogawa, J. Cryst. Spec. Res. 1992, 22, 237247.

[28] M.-Y. Li and S.C. Sevov, Cryst. Eng. Comm. 2013, 15, 5107-5113.

[29] V.A. Uchtman and R.J. Jandacek, Inorg. Chem. 1980, 19, 350-355.
[30] W. Clegg and J.M. Holcroft, Cryst. Growth Des. 2014, 14 , 6282-6293.

[31] J. Pan, F.-L. Jiang, M.-Y. Wu, L. Chen, J.-J. Qian, K.-Z. Su, X.-Y. Wan, M.-C. Hong, Cryst. Eng. Comm. 2014, 16, $11078-11087$

[32] H.-K. Zhao, B. Ding, E.-C. Yang, X.-G. Wang, X.-J. Zhao, Z. Anorg. Allg. Chem. 2007, 633, 1735-1738.

[33] Z.-Q. Liu, Y.-T. Li, Z.-Y. Wu, S.-F. Zhang, Inorg. Chim. Acta. 2009, 362, 71-77.

[34] H. Enders and A. Knieszener, Acta Cryst. 1984, C40, 770-772.

[35] E. Yang, J. Zhang, Z.J. Li, S. Gao, Y. Kang, Y.-B. Chen, Y.H. Wen, Y.-G. Yao, Inorg. Chem. 2004, 6525-6527.

[36] R. Köferstein and C. Robl, Z. Anorg. Allg. Chem. 2005, 631, $1756-1758$

[37] R. Murugavel, D. Krishnamurthy, M. Sathiyendiran, J. Chem. Soc., Dalton Trans. 2002, 34-39.

[38] P.J. Hagrman, D. Hagrman, J. Zubieta, Angew. Chem. 1999, $111,2789-2848$

[39] M. Rafizadeh, V. Amani, S. Zahiri, Acta Cryst. 2007, E63 m1938.

[40] R. Köferstein and C. Robl, Z. Anorg. Allg. Chem. 2003, 629, 2186-2189.

[41] A. Majumder, V. Gramlich, G.M. Rosair, S.R. Batten, J.D Masuda, M.S. El Fallah, J. Ribas, J.-P. Sutter, C. Desplanches, S. Mitra, Cryst. Growth Des. 2006, 6, 2355-2368.

[42] R. Köferstein and C. Robl, Z. Anorg. Allg. Chem. 2004, 630, $185-188$.

[43] X. Y Gong, L. Zhang, Acta Cryst. 2011, E67, m736.

[44] S.M. Humbhrey, R.A. Mole, R.I. Thompson, P.T. Wood, Inorg. Chem. 2010, 49, 3441-3448.

[45] H. Kumagai, Y. Oka, M. Akita-Tanaka, K. Inoue, Inorg. Chim. Acta, 2002, 332, 176-180.

[46] Y.Y. Karabach, A.M. Kirillov, M. Haukka, J. Sanchiz, M.N. Kopylovich, A.J.L. Pombeiro, Cryst. Growth Des. 2008, 8 , 4100-4108.

[47] R. Cao, Q. Shi, D. Sun, M. Hong, W. Bi, Y. Zhao, Inorg Chem. 2002, 41, 6161-6168.

[48] R. Köferstein and C. Robl, Z. Anorg. Allg. Chem. 2003, 629 , 1374-1378.

[49] H. Lin, H. Hu, X. Wang, B. Mu, J. Li, J. Coord. Chem. 2010, $63,1295-1303$

[50] K. Brown, S. Zolezzi, P. Aguirre, D. Venegas-Yazigi, V Paredes-Garcia, R. Baggio, M. A. Novak, E. Spodine, Dalton Trans. 2009, 1422-1427.

[51] L. Alaerts, E. Séguin, H. Poelman, F. Thibault-Starzyk, P.A Jacobs, D.E. De Vos, Chem. Eur. J. 2006, 12, 7353-7363.

[52] Y.Y. Karabach, A.M. Kirillov, M. Haukka, M.N. Kopylovich, A.J.L. Pombeiro, J. Inorg. Biochem. 2008, 102, 1190-1194.

[53] S. Marx, W. Kleist, A. Baiker, J. Catal. 2011, 281, 76-87.

[54] R. Diniz, H.A. de Abrau, W.B. de Almeida, M.T.C Sansiviero, N.G. Fernandes, Eur. J. Inorg. Chem. 2002 11152-1123.

[55] M. Trömel, Acta Cryst. 1984, B40, 338-442.

[56] A. Caron, Acta Cryst. 1969, B25, 404.

[57] A.W. Pryor and P.L. Sanger, Acta Cryst. 1969, B25, 543-558. 
[58] M.O. Sinnokrot, E.F. Valeev, C.D. Sherrill, J. Am. Chem. Soc. 2002, 124, 10887-10893.

[59] L. Han, H.-M. Luo, Q.-H. Meng, Y.-F. Luo, R.-H. Zeng, Acta Cryst. 2010, E66, o68-o69.

[60] H.S. Wilkinson and W.T.A. Harrison, Acta Cryst. 2007, E63, m902-m904.

[61] R. Köferstein and C. Robl, Z. Anorg. Allg. Chem. 2007, 633, $1323-1325$.

[62] A.K. Galwey, M.A. Mohamed, Thermochim. Acta 1994, 239, 211-224.

[63] M.A. Mohamed, A.K. Galwey, S.A. Halawy, Thermochim. Acta 2004, 411, 13-20.

[64] R. Köferstein and C. Robl, Z. Anorg. Allg. Chem., 2014, 640, 1937-1942.

[65] A. Ostasz, R. Lyszczek, L. Mazur, J. Sienkiewicz-Gromiuk, I. Rusinek, Z. Rzaczynska, J. Anal. Appl. Pyrolysis 2013, 99, 203-210

[66] J.E. Stewart, J. Chem. Phys. 1957, 26, 248-254.

[67] F. Gonzalez-Sanches, Spectrochim. Acta 1958, 12, 17-33.

[68] R.B. Penland, S. Mizishima, C. Curran, J.V. Quagliano, J. Am. Chem. Soc. 1957, 79, 1575-1578.

[69] G.S. Manku, Theoretical Principles in Inorganic Chemistry, Tata McGraw-Hill Publishing Company, New Delhi, 2006, p. 532 et seq.

[70] B.N. Figgis and J. Lewis, Prog. Inorg. Chem. 1964, 6, 37-239.

[71] G. M. Sheldrick, Acta Cryst. 2008, A64, 112-122. 


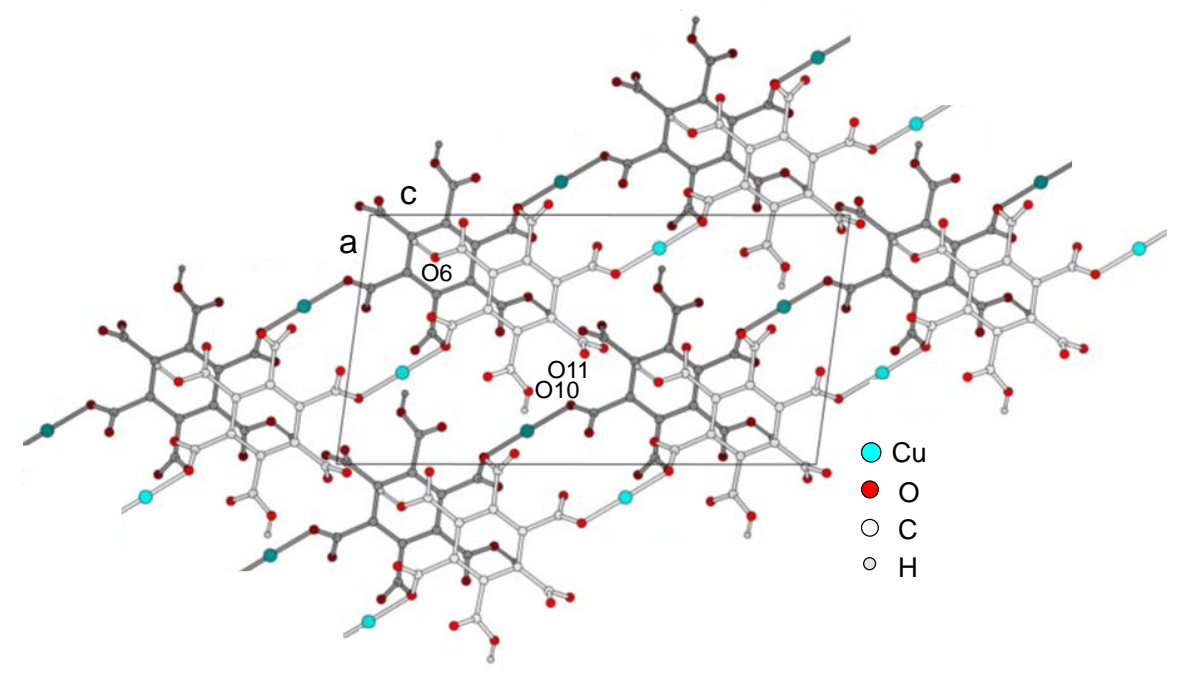

Figure 3. Connection between the $\mathrm{Cu}^{2+}$ cations and the $\left[\mathrm{C}_{6}(\mathrm{COO})_{4}(\mathrm{COOH})_{2}\right]^{4-}$ anions viewed from [010] (urea and water molecules are omitted). Chains lying in the background are marked by darker colours.

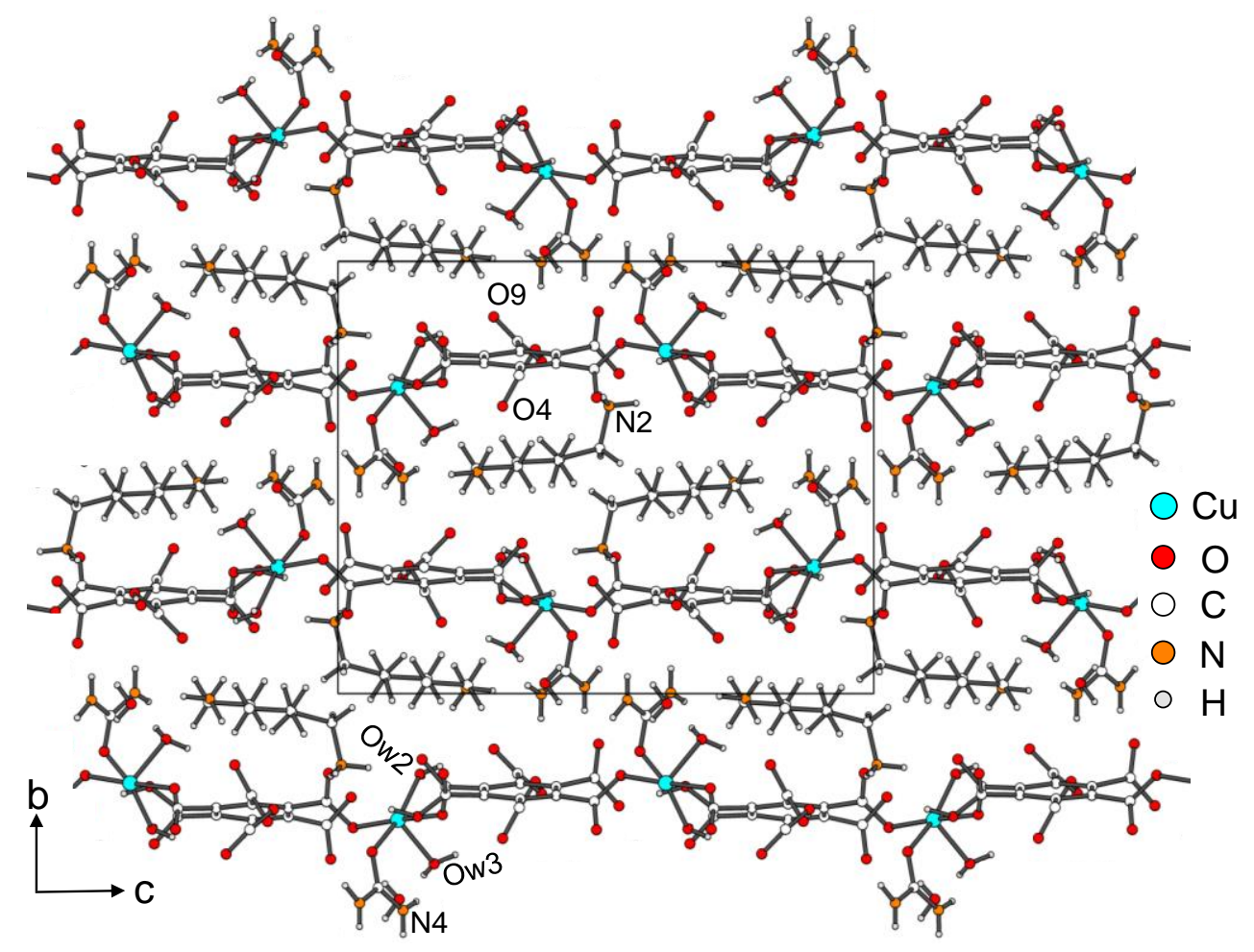

Figure 4. Complete crystal structure of $\left[\mathrm{H}_{3} \mathrm{~N}-\left(\mathrm{CH}_{2}\right)_{6}-\mathrm{NH}_{3}\right]\left[\mathrm{Cu}\left(\mathrm{H}_{2} \mathrm{O}\right)_{2}(\right.$ urea $\left.)\left(\mu_{2}-\mathrm{C}_{6}(\mathrm{COO})_{4}(\mathrm{COOH})_{2}\right)\right] \cdot \mathrm{H}_{2} \mathrm{O}$ viewed along [100]. 